\title{
PENYULUHAN HUKUM MENGENAI KETENAGAKERJAAN DI RT 07 RW 14 KELURAHAN BAHAGIA KECAMATAN BABELAN KABUPATEN BEKASI
}

\author{
Andriyanto Adhi Nugroho', Surahmad ${ }^{2}$ \\ ${ }^{1,2}$ Fakultas Hukum Universitas Pembangunan Nasional Veteran Jakarta \\ Email: andriyan.adhi.n@gmail.com
}

\begin{abstract}
Abstrak
Pengabdian Kepada Masyarakat ini bertujuan untuk memberikan pendampingan dan sosialisasi mengenai hak-hak yang diperloleh tenaga kerja berdasarkan peraturan perundangundangan mengenai tenaga kerja. Analisis terhadap pengaturan tersebut dilakukan dengan instrument hukum yang didasarkan pada Undang-Undang Dasar Negara Republik Indonesia Tahun 1945, Undang-Undang Nomor 13 Tahun 2003 tentang Ketenagakerjaan. Perlindungan terhadap pekerja dimaksudkan untuk menjamin hak-hak dasar pekerja dan menjamin kesamaan kesempatan serta perlakuan tanpa diskriminasi atas apapun untuk mewujudkan kesejahteraan pekerja dan keluarganya dengan tetap memperhatikan perkembangan kemajuan dunia usaha dan kepentingan pengusaha. Peraturan perundang-undangan yang terkait dengan perlindungan bagi pekerja yakni Undang-Undang No. 13 Tahun 2003 tentang ketenagakerjaan dan peraturan pelaksana dari perundang-undangan dibidang ketenagakerjaan. Pengabdian kepada masyarakat ini dilakukan dengan beberapa tahapan, yang terbagi dalam tiga tahapan, yakni (1) Tahap Persiapan Pengabdian Kepada Masyarakat, tahap persiapan dimulai dengan menemukan permasalahan yang akan dibahas dalam Pengabdian Kepada Masyarakat ini. Selanjutnya ditindak lanjuti dengan mengkerucutkan pada judul dan perumusan Pengabdian Kepada Masyarakat. (2) Tahap Pelaksanaan, Tahap ini diawali dengan pengumpulkan data melalui pengabdian kepustakaan dengan mengkaji bahanbahan pustaka yang relevan dengan kajian penelitian kemudian dilengkapi dengan wawancara kepada narasumber untuk melengkapi data pengabdian ini. (3) Tahap Penyelesaian, pada tahap penelitian ini dilakukan dengan menganalisis data penelitian yang ditindaklanjuti dengan penyusunan laporan dan publikasi hasil Pengabdian Kepada Masyarakat.
\end{abstract}

Kata Kunci: Perlindungan Hukum, Pekerja, Hak.

\begin{abstract}
The devotion to the community aims to provide mentoring and socialization of the rights that are being addressed by Labor based on legislation on Labor. Analysis of the arrangement was done with the instrument of law based on the Constitution of the Republic of Indonesia year 1945, Act No. 13 year 2003 on employment. Protection against workers is intended to ensure the basic rights of workers and ensure the similarities of opportunities and treatment without discrimination of any kind to realize the welfare of workers and their families while still paying attention to developments Business progress and entrepreneurs' interests. The legislation related to the protection of the workers of Law No. 13 year 2003 on employment and implementing regulations of the law in the field of employment. The devotion to this community is done by several phases, which are divided into three phases, namely (1) the preparatory phase for community service, the preparation phase begins with finding the problem that will be discussed in the devotion to This society. Further followed by the JURNAL PAPATUNG: Vol. 3 No. 1 Tahun 2020
\end{abstract}

ISSN : 2715-0186 
collapse of the title and formulation of the proposal to community devotion. (2) The stage of implementation, this stage begins with the data-keeping through the dedication of the literature by reviewing the relevant library materials with the research study then supplemented by interviews to the informant to complete the data This devotion. (3) Completion stage, at the stage of this research is conducted by analyzing the research data followed up by the preparation of reports and publications of the results of community devotion.

Keywords: Legal Protection, Workers, Rights.

\section{A. PENDAHULUAN}

Perlindungan hukum terhadap pekerja merupakan pemenuhan hak dasar yang melekat dan dilindungi oleh konstitusi sebagaimana yang diatur dalam Pasal 27 ayat (2) UndangUndang Dasar Negara Republik Indonesia tahun1945 yang berbunyi “ Tiap-tiap warga negara berhak atas pekerjaan dan penghidupan yang layak bagi kemanusiaan", Pasal 33 ayat (1) yang menyatakan bahwa" Perekonomian disusun sebagai usaha bersama atas kekeluargaan”. Perlindungan terhadap pekerja dimaksudkan untuk menjamin hak-hak pekerja dan menjamin kesamaan kesempatan serta perlakuan tanpa adanya diskriminasi atas apapun untuk mewujudkan kesejahteraan pekerja dan keluarganya dengan tetap memperhatikan perkembangan kemajuan dunia usaha dan kepentingan pengusaha. Peraturan perundangundangan yang terkait dengan perlindungan bagi pekerja yakni Undang-Undang Nomor 13 Tahun 2003 tentang Ketenagakerjaan dan peraturan pelaksana dari perundang-undangan dibidang ketenagakerjaan.

Perlindungan yang diwujudkan dalam bidang hukum perburuhan adalah segala sesuatu yang berkenaan dengan hubungan kerja, yang mana pekerjaan dilakukan di bawah pimpinan dan dengan keadaan penghidupan yang berhubungan dengan hubungan kerja itu (Soepomo, 1999). Hubungan kerja menjadi terjalin didasarkan adanya perikatan yang dilakukan pekerja dan majikan dalam bentuk perjanjian kerja. Secara definitif digambarkan bahwa hubungan kerja merupakan hubungan yang terjalin antara pengusaha dan pekerja yang didasarkan perjanjian kerja baik dalam waktu tertentu maupun tidak tentu yang mengandung adanya unsur upah, perintah, dan pekerjaan (Irsan, 2005). Dalam hubungan kerja ini, Pemerintah ikut serta dalam menjamin keberlangsungan hubungan kerja yang dilakukan yaitu dengan pemetaan terhadap instrumen-instrumen yuridis ketenagakerjaan.

Tenaga kerja merupakan faktor penting dalam suatu perusahaan. Semakin berkembangnya teknologi di berbagai sektor usaha semakin besar pula potensi yang dapat mengancam keselamatan dan kesehatan tenaga kerja, oleh karena itu diperlukan usaha untuk 
membina, mengarahkan serta memberikan perlindungan terhadap tenaga kerja (Budiono, 1995). Apabila tenaga kerja diperlakukan sesuai dengan harkat dan martabatnya, maka perusahaan akan mencapai hasil yang sesuai dengan tujuan yang diinginkan oleh perusahaan.

Keselamatan kerja adalah keselamatan yang bertalian dengan mesin, pesawat alat kerja, bahan dan proses pengelolaannya, landasan tempat kerja, dan lingkungannya serta cara-cara melakukan pekerjaan. Jadi definisi tersebut mengarah kepada interaksi pekerja dengan mesin alat yang digunakan atau interkasi pekerja dengan lingkungan kerjanya. Sedangkan kesehatan kerja di perusahaan adalah kondisi bebas dari gangguan fisik, mental, emosi atau rasa sakit yang disebabkan lingkungan kerja. Jadi resiko penyakit dan kecelakaan kerja bisa terjadi kapan saja, untuk itu kesadaran mengenai keselamatan dan kesehatan kerja menjadi sangat diperlukan.

Keselamatan dan kesehatan kerja merupakan hal yang tidak terpisahkan dalam sistem ketenagakerjaan dan sumber daya manusia. Keselamatan dan kesehatan kerja tidak saja sangat penting dalam meningkatkan jaminan sosial dan kesejahteraan para pekerjanya akan tetapi keselamatan dan kesehatan kerja berdampak positif atas keberlanjutan produktivitas kerjanya (Husni, 2010). Oleh sebab itu keselamatan dan kesehatan kerja saat ini bukan sekedar kewajiban yang harus diperhatikan oleh para tenaga kerja, akan tetapi juga harus dipenuhi oleh sebuah sistem pekerjaan. Dengan kata lain, pada saat ini keselamatan dan kesehatan kerja bukan semata sebagai kewajiban, akan tetapi sudah menjadi kebutuhan bagi setiap tenaga kerja dan bagi setiap bentuk kegiatan pekerjaan.

Kesehatan kerja didefinisikan sebagai gejala aturan dan upaya yang bertujuan untuk menyediakan perlindungan teknis bagi pekerja/buruh dari tindakan maupun kondisi yang dapat mengganggu kesehatan fisik, psikis, dan kesusilaannya. Pendapat serupa dikemukakan oleh Iman Soepomo, bahwa kesehatan kerja adalah aturan-aturan dan usaha untuk melindungi pekerja/buruh dari kejadian atau keadaan perburuhan yang merugikan kesehatan dan kesusilaan dalam seseorang itu melakukan pekerjaan dalam hubungan kerja (Poerwanto \& Syaifullah, 2005). Perlindungan tenaga kerja memiliki beberapa aspek dan salah satunya yaitu perlindungan keselamtan, perlindungan tersebut bermaksud agar tenaga kerja secara aman melakukan kerjanya secara aman melakukan kerjanya sehari-hari untuk meningkatkan produktivitas. Menurut Bangun Wilson (2012), keselamatan kerja adalah perlindungan atas keamanan kerja yang dialami pekerja baik fisik maupun mental dalam lingkungan pekerjaan. Menurut Mondy dan Noe, manajemen keselamatan kerja meliputi perlindungan karyawan dari kecelakaan di tempat kerja sedangkan, kesehatan merujuk kepada kebebasan karyawan 
dari penyakit secara fisik maupun mental. Keselamatan kerja menunjukkan pada kondisi yang aman atau selamat dari penderitaan, kerusakan atau kerugian di tempat kerja (Mangkunegara, 2000).

K3 dapat melakukan pencegahan dan pemberantasan penyakit akibat kerja. Norma Kerja berkaitan dengan dengan manajemen perusahaan. K3 dalam konteks ini berkaitan dengan masalah pengaturan jam kerja, shift, kerja wanita atau pria, tenaga kerja kaum muda atau tua, pengaturan jam lembur, analisis dan pengelolaan lingkungan hidup, dan lain-lain. hal tersebut mempunyai korelasi yang erat terhadap peristiwa kecelakaan kerja (Shafira \& Anwar, 2019).

Dosen atau tenaga pungsional diwajibkan melakukan Penelitian maupun Pengabdian Kepada Masyarakat untuk menunjang kegiatan Tri Darma Perguruan Tinggi. Kegiatan Abdimas ini wajib dilaksanakan secara periodik dengan jangka waktu minimal satu tahun. Pengabdian Masyarakat ini dilaksanakan di wilayah RT 07 RW 14 Kelurahan Bahagia Kecamatan Babelan Kabupaten Bekasi.

\section{B. METODE}

Sesuai dengan judul Pengabdian Kepada masyarakat ini, yakni pendampingan. Maka metode pelaksanaan PKM ini dilakukan dengan metode pendampingan. Implementasi riil dari pendampingan dilakukan melalui dari proses berdialog dengan masyarakat sasaran melalui kegiatan pra penyuluhan, setelah itu ditindaklanjuti dengan kegiatan pelatihan dalam bentuk penyuluhan. Keseluruhan kegiatan dilakukan dengan memperhatikan tertib administratif, sehingga setiap kegiatan wajib mendapatkan izin dan dilakukan pencatatan pada kantor kelurahan setempat yang menjadi mitra dalam pelaksanaan pengamdian masyarakat ini.
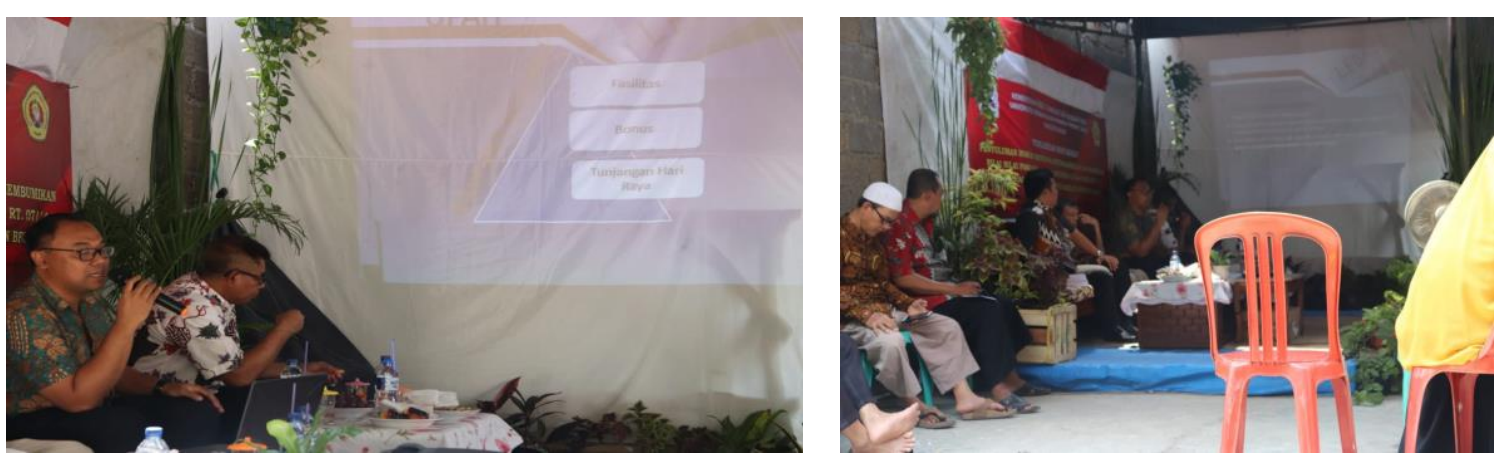

Gambar 1 Gambar Kegiatan Penyuluhan Hukum 


\section{HASIL DAN PEMBAHASAN}

Pelaksanaan kegiatan pengabdian kepada masyarakat di wilayah RT. 07/14 Kelurahan Bahagia Kecamatan Babelan Kabupaten Bekasi dalam bentuk penyuluhan dimaksudkan untuk memberikan Sosialisasi mengenai Hukum Ketenagakerjaan. Adapun tahapan pelaksanaan kegiatan yang dilakukan diawali dengan tahapan persiapan, tahapan penyuluhan, monitoring dan pendampingan, evaluasi dan pembuatan laporan. Pengabdian kepada masyarakat dilakukan dengan khalayak sasaran adalah masyarakat Kelurahan Duren Tiga dengan tujuan dapat memberikan pemahaman (sosialisasi) tentang hukum ketenagakerjaan dan akibat hukumnya kepada masyarakat dilingkungannya sejumlah 70 orang.

Dalam pelaksanaan pengabdian pada masyarakat dilakukan hal-hal sebagai berikut: 1 . Kegiatan pelaksanaan penyuluhan meliputi, pelaksanaan pengabdian pada masyarakat dilaksanakan di wilayah RT 07 RW 14 Kelurahan Bahagia Kecamatan Babelan Kabupaten Bekasi, dengan jumlah peserta sebanyak 70 orang, materi penyuluhan diperbanyak dan diberikan kepada peserta sesuai jumlah yang hadir, sarana prasarana berupa laptop, infocus, layar, wireless, konsumsi dan alat peraga lainnya disiapkan oleh tim pengabdi, dengan susunan acara; pembukaan (penjelasan tentang maksud dan tujuan dilaksanakanya abdimas), kemudian dilanjutkan materi penyuluhan oleh tim pengabdi dan materi diberikan kepada setiap peserta dalam bentuk makalah sekaligus dilanjutkan dengan acara tanya jawab dan ini dilakukan sebanyak 1 (satu) kali kegiatan.

Pada awal dan akhir kegiatan abdimas dilakukan evaluasi, dimana peserta abdimas mengisi kuesioner yang telah disiapkan oleh tim pengabdi sebanyak 70 orang berdasarkan khalayak sasaran yang telah ditentukan dan seluruh kuesioner dikembalikan kepada tim pengabdi. Adapun tujuan dilakukan evaluasi adalah untuk mengetahui sampai sejauh mana pemahaman materi yang telah disampaikan dan tanggapan dari setiap peserta terhadap pelaksanaan abdimas, hasil kuesioner pemahaman materi sebagaimana tercantum pada tabel 1 dan 2 dibawah ini:

Tabel 1

Kuesioner Sebelum Pelaksanaan Abdimas

\begin{tabular}{|c|c|c|c|c|c|c|c|}
\hline \multirow{2}{*}{ No } & \multirow{2}{*}{ Pertanyaan } & \multicolumn{6}{|c|}{ Kriteria } \\
\hline & & $\mathbf{M}$ & $\%$ & $\mathbf{K M}$ & $\%$ & TM & $\%$ \\
\hline 1 & $\begin{array}{l}\text { Apa anda mengerti tentang UU } \\
\text { Ketenagakerjaan }\end{array}$ & 0 & 0 & 7 & 10 & 63 & 90 \\
\hline 2 & Apa anda mengerti hak-hak pekerja & 0 & 0 & 7 & 10 & 63 & 90 \\
\hline 3 & $\begin{array}{l}\text { Apa anda mengerti tentang Kesehatan } \\
\text { dan Keselamatan Kerja }\end{array}$ & 0 & 0 & 2 & 2.85 & 68 & 96.15 \\
\hline
\end{tabular}


Pada tabel 1, menunjukkan hasil untuk pengenalan tentang Undang-Undang Ketenagakerjaan sebanyak 7 orang (10\%) menyatakan kurang mengerti dan 63 orang (90\%) menyatakan tidak mengerti. Untuk hak-hak pekerja sebanyak 7 orang (10\%) menyatakan kurang mengerti dan 63 orang (90\%) menyatakan tidak mengerti. Untuk Kesehatan dan Keselamatan Kerja sebanyak 2 orang $(2.85 \%)$ menyatakan kurang mengerti dan 68 orang $(96.15 \%)$ menyatakan tidak mengerti.

\section{Tabel 2}

\section{Kuesioner Setelah Pelaksanaan Abdimas}

\begin{tabular}{|c|c|c|c|c|c|c|c|}
\hline \multirow{2}{*}{ No } & \multirow{2}{*}{ Pertanyaan } & \multicolumn{6}{|c|}{ Kriteria } \\
\hline & & $\mathbf{M}$ & $\%$ & KM & $\%$ & TM & $\%$ \\
\hline 1 & $\begin{array}{l}\text { Apa anda mengerti tentang } \mathrm{UU} \\
\text { Ketenagakerjaan }\end{array}$ & 68 & 96.15 & 2 & 2.85 & 0 & 0 \\
\hline 2 & Apa anda mengerti hak-hak pekerja & 68 & 96.15 & 2 & 2.85 & 0 & 0 \\
\hline 3 & $\begin{array}{l}\text { Apa anda mengerti tentang Kesehatan } \\
\text { dan Keselamatan Kerja }\end{array}$ & 68 & 96.15 & 2 & 2.85 & 0 & 0 \\
\hline
\end{tabular}

Pada tabel 2, menunjukkan hasil untuk pengenalan tentang UU Ketenagakerjaan sebanyak 68 orang $(96.15 \%)$ menyatakan mengerti, 2 orang $(2,85 \%)$ menyatakan kurang mengerti. Untuk hak-hak pekerja sebanyak 68 orang $(96,15 \%)$ menyatakan mengerti, 2 orang $(2,85 \%)$ menyatakan kurang mengerti. Tentang Kesehatan dan Keselamatan Kerja sebanyak 68 orang $(96,15 \%)$ menyatakan mengerti, 2 orang $(2,85 \%)$ menyatakan kurang mengerti.

Hasil analisis tanggapan peserta abdimas sebelum dan sesudah pelaksanaan menunjukkan bahwa, untuk pengenalan tentang UU ITE adanya peningkatan semula $0 \%$ menjadi $80 \%$ menyatakan mengerti, semula $10 \%$ menjadi $12,5 \%$ menyatakan kurang mengerti, dan semula $90 \%$ menjadi 7,5\% menyatakan tidak mengerti. Untuk penggolongan Kejahatan ITE semula $0 \%$ menjadi $62,5 \%$ menyatakan mengerti, semula $5 \%$ menjadi $22,5 \%$, dan menyatakan kurang mengerti dan semula $95 \%$ menjadi $15 \%$ menyatakan tidak mengerti. Untuk akibat hukum terhadap kejahatan ITE semula 0\% menjadi 70\% menyatakan mengerti, semula 5\% menjadi $15 \%$ menyatakan kurang mengerti dan semula $95 \%$ menjadi $15 \%$ menyatakan tidak mengerti.

Beberapa faktor yang mendukung kegiatan abdimas ini dapat berjalan sesuai rencana antara lain peserta abdimas mempunyai keingintahuan yang besar mengenai sosialisasi UU ITE, hal ini terbukti dengan jumlah peserta yang hadir melebihi dari yang direncanakan. Faktor pendukung lainnya adalah adanya dukungan baik moril maupun materil dari kalangan 
Universitas/ Fakultas, Kelurahan dan pihak-pihak terkait lainnya, sedangkan tim pengabdi sampai saat ini tidak mengalami kendala yang cukup berarti.

\section{KESIMPULAN}

Kegiatan program pengabdian kepada masyarakat merupakan kewajiban bagi setiap dosen dengan melibatkan masyarakat untuk meningkatkan wawasan, pengetahuan dan pemahaman melalui kegiatan pembimbingan, penyuluhan dan pendampingan.

\section{UCAPAN TERIMAKASIH}

Penulis mengucapkan terima kasih kepada UPN Veteran Jakarta yang telah memberi dukungan terhadap pengabdian kepada masyarakat ini.

\section{DAFTAR PURSTAKA}

Bangun, W. (2012). Manajemen Sumber Daya Manusia. Jakarta: Erlangga.

Budiono, A. R. (1995). Hukum Perburuhan di Indonesia. Jakarta: RajaGrafindo Persada.

Husni, L. (2010). Pengantar Hukum Ketenagakerjaan Indonesia. Jakarta: RajaGrafindo Persada

Irsan, K. (2005). Hukum Ketenagakerjaan Suatu Pengantar. Jakarta: Tanpa Penerbit.

Mangkunegara, A. A. A. P. (2000). Manajemen Sumber Daya Manusia. Bandung: Remaja Rosdakarya.

Poerwanto, H., \& Syaifullah. (2005). Hukum Perburuhan Bidang Kesehatan dan Keselamatan Kerja. Jakarta: Badan Penerbit Fakultas Hukum Universitas Indonesia.

Ridley, J. (2008). Ikhtisar Kesehatan \& Keselamatan Kerja. Jakarta: Erlangga.

Shafira, M., \& Anwar, M. (2019). FGD dan Edukasi Tentang Upaya Pencegahan Kekerasan Seksual Dalam Rumah Tangga. DINAMISIA: Jurnal Pengabdian Kepada Masyarakat Universitas Lancang Kuning, 3(2), 198-204.

Soepomo. (1999). Pengantar Hukum Perburuhan. Jakarta: Djambatan

Warman, J. S., Mardian, V., Suryani, L., Fista, F. R., \& Irwan, I. (2019). Program Pelatihan Penigkatan Kemampuan Bahasa Inggris Anak-Anak Panti Asuhan Melalui Pemberdayaan Mahasiswa. DINAMISIA: Jurnal Pengabdian Kepada Masyarakat, 3(2), 280-285. 